\title{
Assessment of Anaemic Children Visited in OPD of Department of Paediatrics in a Tertiary Care Hospital of Western UP
}

\author{
Monica Agarwal ${ }^{1}$ \\ ${ }^{1}$ Assistant Professor, Department of Paediatrics, Rajshree Medical Research Institute \& Hospital, Bareilly, Uttar Pradesh, India.
}

\section{Abstract}

Background: Anemia is accompanied by a reduction in quantity of red blood cells, often along with decreased hemoglobin levels or altered red blood cell morphology. Hence; present study was planned to assess the paediatric patients diagnosed with anaemia. Subjects and Methods: A total of 50 paediatric subjects were included in the present study. Only those subjects were included in the present study in which confirmed diagnosis of anemia was obtained after haematological examination. Detailed clinical details and demographic data of all the subjects were obtained. A self-framed questionnaire was used for obtaining the details of past medical history and family history of all the subjects. All the results were compiled and analysed by SPSS software. Results: Majority of them (64 percent) were females while the remaining 36 percent were males. Significant results were obtained while assessing the gender-wise distribution of anaemic patients. Positive family history of anaemic was found to be present in 36 percent of the patients. 70 percent of the patients of the present study had rural residence, while the remaining 30 percent had urban residence. Gastroenteritis was the most common associated diagnosis found to be present in 30 percent of the patient population. Conclusion: Anemia is a common worldwide hazard affecting significant portion of paediatric population. Higher prevalence of anaemia is seen among females with associated gastric manifestations.

Keywords: Anaemia, Paediatric, Prevalence.

Corresponding Author: Dr. Monica Agarwal, Assistant Professor, Department of Paediatrics, Rajshree Medical Research Institute \& Hospital, Bareilly, Uttar Pradesh, India.

Received: May 2019

Accepted: May 2019

\section{Introduction}

Anemia is accompanied by a reduction in quantity of red blood cells, often along with decreased hemoglobin levels or altered red blood cell morphology. It is the most global nutritional hazard of immense public health significance, affecting subjects all ages, sex and economic group. Among different nutritional deficiency anemias, iron deficiency anemia (IDA) is the commonest. ${ }^{[1-3]}$

The prevalence of iron deficiency anemia is the highest among preschool children. In this age group (6-59 months), body grows rapidly and requires high-iron-rich and nutritious food that may not be fulfilled by their normal diet. Low economic status, less education, and poor health of mothers due to meager dietary intake are the main causes of anemia. ${ }^{[4-6]}$ Hence; present study was planned to assess the paediatric patients diagnosed with anaemia.

\section{Subjects and Methods}

The present study was planned in the Department of Paediatrics, Rajshree Medical Research Institute \& Hospital, Bareilly, Uttar Pradesh, India. The study was conducted with the aim of assessing the anaemic patients visiting the
OPD of the paediatric department. Before the starting of the study, ethical clearance was obtained from the ethical committee. Also written consent was obtained from the parents/guardians of the subjects after explaining in detail the entire research protocol. A total of 50 paediatric subjects were included in the present study. Only those subjects were included in the present study in which confirmed diagnosis of anemia was obtained after haematological examination. Detailed clinical details and demographic data of all the subjects were obtained. A self-framed questionnaire was used for obtaining the details of past medical history and family history of all the subjects. Criteria described previously in the literature were used for defining the criteria for diagnosing anemia among paediatric subjects. ${ }^{[2]}$ All the results were compiled and analysed by SPSS software. Chi- square test was used for assessment of level of significance. P- value of less than 0.05 was taken as significant.

\section{Results}

The present study was planned in the Department of Paediatrics, Rajshree Medical Research Institute \& Hospital, Bareilly, Uttar Pradesh (India) and it included assessment of 
anaemic paediatric patients. A total of 50 anaemic patients were studied in the present study. Mean age of the patients of the present study was 11.4 years. Majority of the patients belonged to the age group of 10 to 12 years. Non- significant results were obtained while assessing the age-wise distribution of anaemic patients.

\begin{tabular}{|c|c|c|c|}
\hline $\begin{array}{l}\text { Age group } \\
\text { (years) }\end{array}$ & $\begin{array}{l}\text { Number of } \\
\text { patients }\end{array}$ & Percentage & p- value \\
\hline Less than 10 & 15 & 30 & \multirow[t]{5}{*}{0.845} \\
\hline 10 to 12 & 17 & 34 & \\
\hline 12 to 15 & 10 & 20 & \\
\hline 15 to 18 & 8 & 16 & \\
\hline Total & 50 & 100 & \\
\hline
\end{tabular}

Table 2: Gender-wise distribution of anaemic patients

\begin{tabular}{|l|l|l|l|}
\hline Gender & $\begin{array}{l}\text { Number of } \\
\text { patients }\end{array}$ & Percentage & p- value \\
\hline Males & 18 & 36 & 0.021 \\
Females & 32 & 64 & (Significant) \\
\hline Total & 50 & 100 & \\
\hline
\end{tabular}

\begin{tabular}{|c|c|c|c|c|}
\hline \multicolumn{5}{|c|}{ Table 3: Clinical data } \\
\hline \multicolumn{2}{|c|}{ Parameter } & $\begin{array}{l}\text { Numbe } \\
\text { r of } \\
\text { patients }\end{array}$ & $\begin{array}{l}\text { Percentag } \\
\text { e }\end{array}$ & p- value \\
\hline \multirow{2}{*}{$\begin{array}{l}\text { Positive } \\
\text { family history } \\
\text { of anemia }\end{array}$} & Yes & 18 & 36 & \multirow{2}{*}{$\begin{array}{l}0.031 \\
\text { (Significant } \\
\text { ) }\end{array}$} \\
\hline & No & 32 & 64 & \\
\hline \multirow[t]{2}{*}{ Residence } & Rural & 35 & 70 & \multirow{2}{*}{$\begin{array}{l}0.012 \\
\text { (Significant } \\
\text { ) }\end{array}$} \\
\hline & Urban & 15 & 30 & \\
\hline \multirow{4}{*}{$\begin{array}{l}\text { Associated } \\
\text { manifestation } \\
\mathrm{s}\end{array}$} & $\begin{array}{l}\text { Gastroenteriti } \\
\mathrm{s}\end{array}$ & 15 & 30 & \multirow{4}{*}{$\begin{array}{l}0.022 \\
\text { (Significant } \\
\text { ) }\end{array}$} \\
\hline & $\begin{array}{l}\text { Respiratory } \\
\text { infection }\end{array}$ & 5 & 10 & \\
\hline & Asthma & 3 & 6 & \\
\hline & Others & 3 & 6 & \\
\hline
\end{tabular}

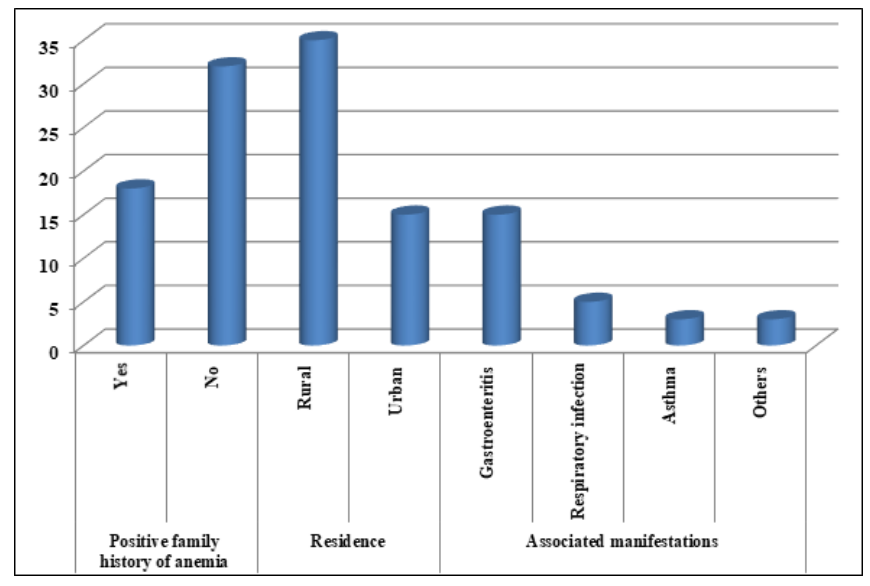

Figure 1: Clinical data

Among the 50 anaemic patients analysed in the present study, majority of them (64 percent) were females while the remaining 36 percent were males. Significant results were obtained while assessing the gender-wise distribution of anaemic patients. Positive family history of anaemic was found to be present in 36 percent of the patients. 70 percent of the patients of the present study had rural residence, while the remaining 30 percent had urban residence. Gastroenteritis was the most common associated diagnosis found to be present in 30 percent of the patient population.

\section{Discussion}

Anemia is a worldwide community health hazard with an associated elevated risk of morbidity and mortality, more commonly in pregnant females and adolescents. Worldwide, 1.62 billion subjects are anaemic, while 47.4 percent is the prevalence of anaemia among preschool children. Nearly fifty percent of the worldwide anaemia cases are accounted by nutritional anaemia affecting the South Asia. In our country, it continues to be the most common health problem in adolescents, and pregnant women. Approximately 50\% of the population suffers from nutritional anemia as known in countries where meat consumption is low. ${ }^{[7-9]}$

The present study included assessment of anaemic paediatric patients. A total of 50 anaemic patients were studied in the present study. Mean age of the patients of the present study was 11.4 years. Majority of the patients belonged to the age group of 10 to 12 years. Non- significant results were obtained while assessing the age-wise distribution of anaemic patients. In a previous study done by Dos Santos $\mathrm{RF}$ et al, authors assessed the incidence of anemia and it correlating factors in subjects a children's hospital in Recife. A total of 595 male subjects and female children with agerange between 6 to 59 months old were included in their study. They defined anaemia in their study as paediatric subjects with a hemoglobin concentration less than $11 \mathrm{~g} / \mathrm{dL}$. They used the Poisson regression analysis method for assessing the association between studied parameters and anemia. The total prevalence of anaemia in their study was found to be 56.6 percent. They observed a significant correlation of occurrence of anaemia with low weight, young age and a diagnosis of acute lower respiratory disease. The high incidence of anemia proposed that it might contribute as a causative agent for hospitalization, mostly because the period of hospitalization was short and the patient was likely to be anemic at the time of admission. This study emphasized on the importance of assessing the overall nutritional status of patients, including their ingestion of microelements. ${ }^{[10]}$

Among the 50 anaemic patients analysed in the present study, majority of them (64 percent) were females while the remaining 36 percent were males. Significant results were obtained while assessing the gender-wise distribution of anaemic patients. Positive family history of anaemic was found to be present in 36 percent of the patients. 70 percent of the patients of the present study had rural residence, while the remaining 30 percent had urban residence. Gastroenteritis was the most common associated diagnosis 
found to be present in 30 percent of the patient population. The incidence and risk factors of anaemia were assessed in another study by Rocha Dda S et al. Assessment of a total of 312 paediatric subjects with the age range of 7 to 59 months was done, who attended daycare centers of the East Sanitary District of Belo Horizonte. From the finger stick blood samples, using the HemocueTM portable photometer, they diagnosed the anaemia cases. For this, they considered the hemoglobin levels below $11.0 \mathrm{~g} / \mathrm{dL}$. For assessing the nutritional status of the subjects, they measured the weight and height of the subjects followed by classification according to WHO criteria. Parameters were gathered through a questionnaire replied by subject's parents or guardians, containing socioeconomic variables, along with data on maternal and children's health. The occurrence of anemia in the population studied was $30.8 \%$, with a higher prevalence in children $\leq 24$ months of age $(71.1 \%)$. Risk factors for anemia were age $\leq 24$ months (OR: $9.08 \mathrm{CI}: 3.96$ to 20.83), and height-for-age <-1 z-score (OR: 2.1, CI: 1.20 to 3.62). The high prevalence of anemia in children attending day care centers in Belo Horizonte, especially those younger than 24 months and in children with heightfor-age $<-1$ z-score, demonstrates the importance of nutritional care to infants and strengthens the need for commitment of child care institutions in reducing this deficiency. ${ }^{[11]}$

\section{Conclusion}

From the above mentioned data, it can be concluded that anemia is a common worldwide hazard affecting significant portion of paediatric population. Higher prevalence of anaemia is seen among females with associated gastric manifestations. Hence; periodic paediatric check-up should be done so that early diagnosis and prompt treatment planning of this pathology could be done.

\section{References}

1. Osório MM, Lira PIC, Batista-Filho M, Ashworth A. Prevalence of anemia in children 6-59 months old in the state of Pernambuco, Brazil. Rev Panam Salud Publica. 2001; 10(2): 101-7.

2. World Health Organization Iron deficiency anemia assessment, prevention and control. A guide for programme managers. Geneva; WHO; 2001.

3. Neves MB, Silva EM, Moraes MB. [Prevalence and factors associated with iron deficiency in infants treated at a primary carecenter in Belém, Pará, Brazil]. Cad Saúde Pública. 2005; 21 (6): 1911-8.

4. Umbelino DC, Rossi EA. Deficiência de ferro: conseqüências biológicas e propostas de prevenção. Rev Ciênc Farm Básica Apl. 2006; 27(2): 103-12.

5. Travassos C, Noronha JC, Martins M. Morbidade hospitalar como indicador de qualidade: uma revisão. Ciênc Saúde Coletiva. 1999; 4(2): $367-81$.

6. Freire WB, Dirren H, Barclay D. Iron deficiency anemia in Ecuador In: Hercberg S, Galan P, Dupin H. Recent knowledge on iron and folate deficiencies in the world. Paris: Collogue INSEAM; 1990. p. 47-54.

7. Torres MA, Braga JA, Taddei JA, Nóbrega FJ. [Anemia in lowincome exclusively breastfed infants]. J Pediatr (Rio J). 2006; 82 (4): 284-7.

8. Neuman NA, Tanaka OY, Szarfarc SC, Guimarães PR, Victora CG. Prevalência e fatores de risco para anemia no Sul do Brasil. Rev Saúde Pública. 2000; 34(1): 56-63.

9. Villapando S, Shamah LT, Ramirez-Silva CI, Nejia-Rodrigues F, Rivera JA. Prevalence anemia in children to 12 years of age. Results from a nation wide probabilistic survey in Mexico. Salud Publica Mex. 2003; 45Suppl 4: 490-8.

10. Dos Santos RF, Gonzalez ES, de Albuquerque EC, et al. Prevalence of anemia in under five-year-old children in a children's hospital in Recife, Brazil. Rev Bras Hematol Hemoter. 2011;33(2):100-4.

11. Rocha Dda S, Capanema FD, Pereira Netto M, Franceschini Sdo C, Lamounier JA. Prevalence and risk factors of anemia in children attending daycare centers in Belo Horizonte--MG. Rev Bras Epidemiol. 2012 Sep;15(3):675-84.

Copyright: () the author(s), 2019. It is an open-access article distributed under the terms of the Creative Commons Attribution License (CC BY 4.0), which permits authors to retain ownership of the copyright for their content, and allow anyone to download, reuse, reprint, modify, distribute and/or copy the content as long as the original authors and source are cited.

How to cite this article: Agarwal M. Assessment of Anaemic Children Visited in OPD of Department of Paediatrics in a Tertiary Care Hospital of Western UP. Asian J. Clin. Pediatr. Neonatol.2019;7(2):34-36.

DOI: dx.doi.org/10.21276/ajcpn.2019.7.2.9

Source of Support: Nil, Conflict of Interest: None declared. 